\title{
ON SUPPOSED THERMAL SPRINGS IN CAMBRIDGESHIRE.
}

Sin, - A paper was read at the late meeting of the British Association by Mr. Harmer, "On some Thermal Springs in the Fens of Cambridgeshire." I have not had an opportunity of visiting them, but, knowing the general character of the district, I have thought over the matter, and asked myself whether, since they are stated to be shallow farmyard wells, the temperature of the water may not be due to fermenting manure. To-day $I$ went into a farmyard in this village, and found them laying up the manure in heaps, previous to carting it away upon the land. The manure was already hot and steaming when they removed it from the area of the yard, on which it lay two feet deep. There stands a pump in the centre of the yard; and $I$ asked the farm-servant, who lives on the spot, whether the water was warm. "Yes," said he, "almost as warm as new milk. And so is the water from the other well" (which stands on the edge of the yard). I fetched a thermometer, and found the water in the yard at $65^{\circ}$ Far., that in the well on the edge of the yard at $54^{\circ}$, while the temperature of the air was $44^{\circ}$. Snow has been lying on the ground for five days, and disappeared only last night. In thawing it has gone into the farmyard well, and discoloured the water; else probably the temperature might have been higher, for the workman considered the water less warm than usual. In these wells the water stands at about twelve feet from the surface. They are fed by springs from the lower chalk, the water being held up by the gault. In such a country as this, the idea of Thermal springs being fed by faults from below seems improbable, since, though there may be faults, it is scarcely possible that open fissures can exist in the soft clays of the district.
Harditon, Cambridgeshire, Dec. $13,1870$.
O. Fisher.

\section{THE ALLEGED OCCURRENCE OF MACHAIRODUS LATIDENS IN KENT'S CAVERN, TORQUAY.}

SIR,-Your readers are doubtless aware that in certain English museums there are canines of Machairodus latidens (formerly known as Ursus cultridens), said to have been found in Kent's Cavern, by the late Rev. J. MacEnery ; and that some palæontologists, including M. E. Lartet and the late Dr. Falconer, have doubted whether they really did belong to the Cavern series.

In 1869 I printed all the evidence which existed on the subject, so far as was then known, ${ }^{1}$ and have reason to believe that the doubts mentioned above were fully disposed of.

My present object, however, is to ask for sufficient space in your MaGazine to record an unpublished fact having an important bearing on the question. Through the kindness of Professor Phillips, I have recently found that in May, 1826, Mr. MacEnery sent to the Museum of the Yorkshire Philosophical Society a set of specimens

1 See Trans. Devon Assoc., vol. iii., pp. 481-494. 1869. 